Bartosz Chrząszcz*

ORCID: 0000-0001-8344-0420

Uniwersytet Wrocławski

https://doi.org/10.19195/1733-5779.37.7

\title{
Bezkompromisowa ucieczka do dyktatury. Teologia polityczna Juana Donoso Cortésa
}

JEL Classification: K19, N43, Z12

Słowa kluczowe: dyktatura, konserwatyzm hiszpański, kontrrewolucja, ład prawdziwy

Keywords: dictatorship, Spanish conservatism, counterrevolution, real order

Abstrakt: Krytyka rewolucji nie jest właściwa wyłącznie myślicielom francuskim. Reakcjonizm odnosi się do tych, których dotknęła klęska ancien régime’u. W nurt ten wpisuje się Juan Donoso Cortés, a niniejszy artykuł służy uważnemu przeanalizowaniu jego osoby pod kątem przemiany światopoglądowej i krytyki doktryn o rewolucyjnym rodowodzie oraz przedstawieniu śmiałej koncepcji tego dyplomaty, to jest dyktatury w imię ładu prawdziwego. Choć hiszpański konserwatysta nie stworzył przywołanej koncepcji całkowicie od podstaw, gdyż opierał się na doktrynie Josepha de Maistre'a, to jednak należy stwierdzić, że rozwinął ją, obudowując dodatkowo ideowym uzasadnieniem. Przejawiając zakorzenione w platońsko-augustiańskiej filozofii podejście pesymistyczne, wyrażał postawę bliską francuskiej odmianie tradycjonalizmu. Inicjator decyzjonizmu z jednej strony oraz kontynuator tradycjonalistycznych zwyczajów z drugiej, sformułował intrygującą konstrukcję będącą zarówno kontynuacją wielu stanowisk myśli konserwatywnej, jak i - przy zachowaniu wyraźnie zachowawczych tendencji — otwarciem jej na nowe rozwiązania. Wszystko dla urzeczywistnienia największego celu — obrony ładu prawdziwego.

\section{An uncompromising escape to dictatorship: The political theology of Juan Donoso Cortés}

\begin{abstract}
Criticism of revolution is not unique to French thinkers. Reactionism refers to philosophers who have suffered due to the defeat of the ancien régime. Juan Donoso Cortés is part of this trend, and this article is intended to carefully analyze his character regarding the change in his worldview as well as his critique of doctrines based on revolutionary ideas, and to present his bold concept - a dictatorship in the name of real order. Although it should be stated that the Spanish conservative did not create it completely from scratch, basing on the doctrine of Joseph de Maistre, he still developed it with an additional ideological justification. Showing a pessimistic approach
\end{abstract}

* Opiekun naukowy (Scientific Tutor) — prof. dr hab. Mirosław Sadowski 
rooted in the Platonic-Augustinian philosophy, he expressed an attitude close to the French version of traditionalism. A continuator of traditionalist customs on the one hand, and the initiator of decisionism on the other, he formulated an intriguing structure that both preserved many traditions of conservative thought and, while maintaining clearly conservative tendencies, opened it to new solutions. All of this in order to achieve the chief aim — defending the real order.

\section{Wprowadzenie}

Juan Donoso Cortés, zaliczany do grona najwybitniejszych „,doktorów kontrrewolucji”, wpisywał się w nurt tradycjonalistyczny zapoczątkowany przez Josepha de Maistre'a ${ }^{1}$. Nazywany uczniem francuskiego reakcjonisty sformułował filozofię polityczną, która zachowując ówczesne standardy postrzegania tradycjonalizmu, wprowadzała elementy wcześniej w nim nieobecne lub wzmiankowane jedynie w sposób marginalny. Do czynników tych zalicza się w szczególności Cortésowska koncepcja dyktatury (zaczerpnięta w pewnym zakresie od wskazanego Sabaudczyka), która będzie przedmiotem rozważań w niniejszym artykule. Jej prezentację w fundamentalnej Mowie o dyktaturze z 4 stycznia 1849 roku poprzedza druzgocąca krytyka, jakiej poddawane były racjonalizm, liberalizm i socjalizm. Krytyka ta pojawia się na tle obecnej już wcześniej pochwały przedrewolucyjnego ładu, przez co powstaje wizja restauracji owego porządku wpisana w charakterystyczną dla Donoso Cortésa narrację zdecydowanej potrzeby przeciwdziałania wszelkim ruchom wywrotowym, takim jak rewolucja francuska czy obserwowana przez niego Wiosna Ludów.

W latach 1847-1850 Donoso Cortésa dotknął poważny kryzys mistyczny prowadzący do gruntownej przebudowy jego systemu wartości. Przejście z obozu umiarkowanie konserwatywnego do obozu bezwzględnej kontrrewolucji wynikało z dwóch istotnych wydarzeń. Po pierwsze, śmierci brata, będącego przykładnym katolikiem i karlistą, po drugie zaś Wiosny Ludów, nazywanej przez

1 J. Trybusiewicz, De Maistre, Warszawa 1968, s. 114. Autor określa Donoso Cortésa kontynuatorem francuskiej odmiany doktryny tradycjonalistycznej. Hiszpan nie utożsamiał się ze swoimi rodakami „karlistami”, krytykując ich za zbyt daleko idącą skrajność. Por. J. Bartyzel, U źródet „Syllabusa”. Donoso Cortés versus katolicy liberalni, „Arcana: Kultura, Historia, Polityka” 2009, nr 90 (6), s. 96-110. Tradycjonalizm francuski i karlistowski różniła w szczególności podstawa ideologiczna. Jak zauważa Adam Wielomski, teologia polityczna francuskiej kontrrewolucji, w tym hiszpańskiego myśliciela, oparta była na tradycji platońsko-augustyńskiej postrzegającej Boga jako byt surowy, absolutny, karzący człowieka w sposób bezwzględny, gdy nie postępuje on w myśl Jego nakazów. Prezentowana tu antropologia ma zatem wymiar pesymistyczny, odmiennie od karlistowskiej, tomistycznej, wyróżniającej się większym optymizmem. Człowiek nie był w tej konwencji dogłębnie skażony grzechem. Wizję decyzjonistycznego suwerena zastępuje postulat utworzenia wiejskiej wspólnoty nawiązującej do czasów feudalnych. To pozwoli odtworzyć na ziemi hierarchiczny, tomistyczny ład, idealny do właściwego funkcjonowania człowieka według Boskich zamierzeń. Zob. A. Wielomski, Filozofia polityczna francuskiego tradycjonalizmu: 17961830, Warszawa 2013, s. 183-184. 
niego „horrorem rewolucji europejskiej”2. Doprowadziło to Donoso Cortésa do poszukiwania argumentów przeciwko postępowi, który wydawał się już nieodwracalny, wyrażania niechęci wobec tendencji przypieczętowujących zgon ancien régime'u, a także przeprowadzenia analizy rewolucyjnego spustoszenia obejmującego w coraz większym stopniu Europę w stylistyce jednoznacznie pejoratywnej, akcentującej zakorzenione w rewolucji zło, zmierzające do całkowitej dekompozycji porządku politycznego ${ }^{3}$.

Celem artykułu jest wykazanie, że myśl Juana Donoso Cortésa stanowi moment przejściowy od tradycjonalizmu do decyzjonizmu, zawierając w sobie aspekty bliskie nurtom obu doktryn zachowawczych. Badania poświęcone analizie twórczości hiszpańskiego dyplomaty pozwalają twierdzić, że swoimi postulatami zapewnia on płynną transformację zakorzenionej $\mathrm{w}$ tradycjonalizmie inspiracji w decyzjonistycznie zorientowaną filozofię niemieckiego konserwatysty Carla Schmitta, który w swojej Teologii politycznej z 1922 roku opisuje wpływ de Maistre'a, de Bonalda oraz Donoso Cortésa ${ }^{4}$. Realizacja założonego celu wymaga przeprowadzenia rekonstrukcji światopoglądu hiszpańskiego uczonego przez wskazanie na fundamentalne dla niej kwestie, w które wpisuje się zarówno wskazana krytyka, jak i potrzeba zagwarantowania społeczeństwu stabilizacji za pomocą silnych rządów służących urzeczywistnieniu porządku prawdziwego. Zobrazuje to podstawowy problem badawczy dyktatury przedstawianej na tle teologii politycznej Juana Donoso Cortésa, wzbogacającej rozwój dyskursu zachowawczego.

2 Na początku swojej politycznej kariery Donoso Cortés pozostawał liberałem. Należał do partii liberalnej, jednakże sytuował się na prawym jej skrzydle reprezentowanym przez umiarkowanych polityków określanych mianem moderados. Około czterdziestego roku życia zaczął głosić filozofię, którą znamy współcześnie. Na skutek wspomnianych wydarzeń przeszedł z apologii parlamentaryzmu liberalnego do jego krytyki, a liberalny katolicyzm zastąpił tradycjonalizmem mistycznym. Zob. F. Morgan, Juan Donoso Cortés, obserwator rewolucji w Europie, [w:] Czarna księga rewolucji francuskiej, red. R. Escande, przeł. B. Biały et al., Dębogóra 2015, s. 635; por. P. Viereck, Conservatism: From John Adams to Churchill, Princeton 1956, s. 15.

${ }^{3}$ F. Morgan, op. cit., s. 633. O narodzinach ultramontanina i „reakcjonisty w imię Boga” szeroko rozpisuje się również Bogdan Szlachta, konkludując, że to właśnie „nowy” Donoso Cortés, który na skutek przewartościowania swojego podejścia do czynnika religijnego był w stanie, dochodząc do stricte tradycjonalistycznych konkluzji, przewidzieć nadejście socjalistycznego Antychrysta. Miało to stanowić ostatni czynnik ukierunkowujący markiza de Valdegamas do opracowania koncepcji „decyzji pochodzącej z góry”. Zob. B. Szlachta, Między tym, co popularne a tym, co zdrowe. Uwagi o krytykach (i koncepcjach) politycznych Donoso Cortésa, [w:] J. Donoso Cortés, O katolicyzmie, liberalizmie i socjalizmie. Wybór pism, przeł. M. Wójtowicz-Wcisło, Kraków 2017, s. XIII.

${ }^{4}$ C. Schmitt, Teologia polityczna i inne pisma, przeł. M.A. Cichocki, Warszawa 2012, s. 92-104. 


\section{Zarys światopoglądowy i teologia polityczna Juana Donoso Cortésa}

Poglądy polityczne Donoso Cortésa uzupełniały się wzajemnie ze sposobem pojmowania prawa w mającej się nieuchronnie zmienić rzeczywistości. Hiszpański uczony, podejmując się uzasadnienia kwestii „dyktatury prawowitości” i legitymizacji władzy, prowadził rozważania zmierzające do ustalenia osoby mającej za zadanie odtworzenie ładu prawdziwego wybiegające poza klasyczny schemat monarchicznego panowania. Obejmująca ten aspekt refleksja umożliwia konstatację, że ani siła militarna państwa, ani szlachetna wersja dyktatury — określanej w nomenklaturze pojęciowej markiza de Valdegamas „dyktaturą szabli” — nie doprowadzą do ostatecznego odrodzenia Europy. Mamy bowiem do czynienia z przemianami zakrojonymi na niewyobrażalnych rozmiarów skalę, gdzie potrzeba siły znacznie większej, siły, którą zapowie wielka przemiana religijna ${ }^{5}$. Stwierdzenie to ujawnia w filozofii hiszpańskiego reakcjonisty inny istotny element, jakim jest mocne przywiązanie do katolickich tradycji, o czym wielokrotnie wzmiankuje w swojej popisowej pracy - Eseju o katolicyzmie, liberalizmie $i$ socjalizmie. Teologia katolicka w największym stopniu ukształtowała wizję dyktatury Donoso Cortésa w dokumentnym wyartykułowaniu wartości o walorze pryncypialnym, zbudowaniu krytyki rewolucyjnych doktryn w oparciu o te prawidła, a w szczególności w utworzeniu ideologicznej obudowy dla uzasadnienia śmierci cywilizacji, co miało być najbardziej brutalną konsekwencją rewolucyjnego przewrotu.

Donoso Cortés podkreśla, że bez popadania w nadmierny panteizm skonkludować można, iż wszystkie rzeczy istnieją w Bogu, podobnie jak Stwórca egzystuje we wszystkich rzeczach ${ }^{6}$. Analiza dzieł markiza de Valdegamas wskazuje, że stwierdzenie to będzie ich motywem przewodnim unaoczniającym się już we wstępie do Eseju o katolicyzmie, liberalizmie i socjalizmie, gdzie autor, polemizując $\mathrm{z}$ anarchoindywidualistą Pierre-Josephem Proudhonem, przekonuje, że obecność teologii we wszystkich kwestiach politycznych nie jest niczym zadziwiającym ${ }^{7}$.

Z katolicyzmu wywodzi się idea autorytetu, ten zaś implikuje dyktaturę. Opierając się na tym, hiszpański myśliciel wskazuje, że Chrystus sprawuje suwerenną

5 J.M. Beneyto, Apocalipsis de la modernidad: El decisionismo político de Donoso Cortés, Barcelona 1993, s. 91, cyt. za: J. Bartyzel, Uźródel „Syllabusa”...

6 J. Donoso Cortés, Esej o katolicyzmie, liberalizmie $i$ socjalizmie rozważanych $w$ ich fundamentalnych zasadach, [w:] idem, O katolicyzmie..., s. 5-6.

7 Zob. P.-J. Proudhon, Zwierzenia rewolucjonisty, [w:] idem, Wybór pism, t. 1, Warszawa 1974. W oryginale: Les confessions d'un révotionnaire, Paris 1851. Zakwestionowanie spostrzeżeń Proudhona przychodzi markizowi de Valdegamas z niezwykłą łatwością, kiedy w metaforyczny sposób opisuje teologię jako ocean, który zawiera i obejmuje wszystkie nauki, podobnie jak Bóg jest oceanem zawierającym i obejmującym w sobie wszystkie rzeczy. 
władzę za pośrednictwem papieża uosabiającego Jego świętość. Tylko w społeczeństwie katolickim idea władzy oraz jej wdrażanie opiera się nie na sile, lecz na zgodzie. Definicja suwerennej władzy, którą sprawują książęta, zawarta jest w składanych w chwili sakry królewskiej deklaracjach Kościoła podkreślających obowiązki z nią związane ${ }^{8}$. Ład w prowadzony przez katolicyzm przeszedł zatem ze świata religijnego do świata moralnego, a następnie do świata politycznego, gdzie panuje jedna zasada stanowiąca, że w społeczeństwie katolickim absolutnie niemożliwe są dwie rzeczy: despotyzm i rewolucje9 .

Konkluzja ta jest jedną z najbardziej znaczących z perspektywy myśli markiza de Valdegamas. Pozwala zrozumieć nie tylko zasygnalizowaną wcześniej prawidłowość interpretacyjną, która wymaga odniesienia się do katolickiej konwencji obejmującej całą twórczość Donoso Cortésa, ale przede wszystkim stanowi zapowiedź tego, co się stanie, jeżeli jego przesłanie zostanie urzeczywistnione. Przez utworzenie na nowo społeczeństwa całkowicie katolickiego zwycięstwem zakończy się walka z destabilizującą Europę rewolucją. Ta zaś nigdy się już nie powtórzy. Dyktatura natomiast doprowadzić ma jedynie do samego przezwyciężenia porewolucyjnego kwestionowania porządku prawdziwego celem jego przywrócenia i z natury z despotyzmem kojarzona być nie może.

Rewolucja francuska, podobnie jak Wiosna Ludów, wybuchła pod hasłami liberalnie pojmowanej wolności, a motywowana była wartościami emancypacyjnymi. Obydwa wydarzenia zmierzały do negacji teologii i dotychczasowej polityki. W kontekście polemiki Donoso Cortésa z Proudhonem należy wyszczególnić, że rewolucyjna teologia polityczna opiera się na triadzie ateizm-anarchizm-socjalizm, podczas gdy ta kontrrewolucyjna na wyodrębnieniu katolicyzmu, legitymizmu i własności ${ }^{10}$. Scena polityczna nie dzieli się jednak u reakcjonisty na obóz rewolucyjny i kontrrewolucyjny, ale na kontrrewolucyjny (broniący autorytarnego i katolickiego ładu); liberalny (postulujący utworzenie niezależnej od czynnika religijnego monarchii konstytucyjnej) i socjalistyczny (dążący do utworzenia antyklerykalnej i ateistycznej republiki podważającej własność prywatną).

Na kanwie polemiki z Proudhonem Donoso Cortés kreuje własną teologię polityczną, która będzie wyznaczać dalszą charakterystykę jego myśli. Hiszpan jest w pełni świadom analogii zachodzących między płaszczyzną teologiczną i polityczną ${ }^{11}$. W tym miejscu poprzestaniemy na wyszczególnieniu nakreślonych przez markiza de Valdegamas analogii — te zostaną omówione w kolejnych partiach tekstu. W ocenie reakcjonisty wyróżnić można następujące pary: monarchia absolutna i katolicyzm, liberalizm i deizm, socjalizm i panteizm, ateizm $i$ anarchia, cud

8 F. Morgan, op. cit., s. 646.

9 J. Donoso Cortés, Esej o katolicyzmie..., s. 20-21.

10 A. Wielomski, W poszukiwaniu Katechona. Teologia polityczna Carla Schmitta, Radzymin 2017, s. 122.

11 Ibidem, s. 125. 
z bezpośrednimi rządami Opatrzności i dyktatura ${ }^{12}$. Każde zestawienie zawiera w sobie związek twierdzenia politycznego z religijnym, co wzmacnia argumentację, czyniąc ją spójną i kompletną.

\section{Dlaczego rewolucja wymaga reakcji w postaci dyktatury?}

\section{1. Śmierć cywilizacji}

Dyskurs zachowawczy przekonuje konsekwentnie, że począwszy od wybuchu rewolucji francuskiej w 1789 roku, każda kolejna nagła i nierzadko wręcz destrukcyjna zmiana była błędem. Podobnie twierdził Donoso Cortés, sprowadzając ówcześnie popełniane błędy (a pozostające pokłosiem rewolucyjnych przewartościowań) do dwóch zasadniczych: przeczenia Opatrzności oraz przeczenia grzechowi. Zatrważająca zdaniem hiszpańskiego konserwatysty jest wypływająca z nich konsekwencja odzwierciedlająca się w negacji dogmatu suwerenności Trójcy Świętej, a tym samym Bożego zwierzchnictwa ${ }^{13}$. Rewolucja prowadzi zatem nieuchronnie do zniszczenia wszelkiego pojęcia porządku politycznego. Jednakże zanim markiz de Valdegamas taką konkluzję sformułował, miał okazję obserwować przez wiele lat sytuację społeczno-polityczną swojego kraju, ta z kolei nie prezentowała się najlepiej. Historyczne wydarzenia, które zaistniały we Francji, nie przeszły bez echa w Hiszpanii, gdzie po zakończeniu wojen napoleońskich miała miejsce rewolucja liberalna odznaczająca się chaotycznością oraz brutalnością. Ojczyzna Donoso Cortésa nie była stabilna pod względem politycznym, a jej podatność na nowe doktryny stawała się coraz bardziej widoczna ${ }^{14}$.

Żyjąc w warunkach niepewności i zataczającego coraz szersze kręgi odwracania się od ładu przedrewolucyjnego, który stabilizował funkcjonowanie państw europejskich, oraz uświadamiając sobie stopniowo zagrożenie wynikające z zyskujących popularność doktryn, reakcjonista w zdecydowany sposób piętnuje demagogię i demaskuje jej prawdziwe oblicze ${ }^{15}$. Wszystko to czyni w obronie

12 Ibidem, s. 129.

13 R. Cammilleri, Juan Donoso Cortés. Il padre del Sillabo, wstęp G. Baget Bozzo, Genova 1998, s. 147. Włoski badacz dostrzega, że wyartykułowanie przez hiszpańskiego myśliciela błędów, których ludność europejska wielokrotnie dopuszczała się na przełomie XVIII i XIX wieku, prowadzi do wniosku, że w ten sposób niemal całkowicie zanegowano niezwykle cenny dla każdego reakcjonisty ład absolutny. Mając to na względzie, markiz de Valdegamas podnosi zatem, że wszelkie wysiłki powinny skupić się na tym, aby odwrócić podobny stan rzeczy. W tym celu istniejącym błędom należy przeciwstawić tezę o potrzebie zachowania niezmiennego porządku, podkreślać prymat porządku nadnaturalnego nad naturalnym, Kościoła nad państwem i Opatrzności nad wolnością. Zob. J. Bartyzel, U źródet ,, Syllabusa”...

14 Mocne zakorzenienie liberalizmu w pierwszej połowie XIX wieku w Hiszpanii opisuje dokładniej J. Pérez, Histoire de l'Espagne, Paris 1996, s. 554.

15 J. Donoso Cortés, L'Église et la Révolution, [w:] idem, Euvres de Donoso Cortés, t. 2, Paris 1862, s. 121. Hiszpan obnaża demagogię doktryn, które ukształtowały się na zgliszczach rewolucyjnych przemian, przez dokumentne wskazanie, co za ich sprawą miało miejsce w największych 
tego, co w jego ocenie zostało już poważnie osłabione. Rewolucja w opisach hiszpańskiego zachowawcy ukazuje się jako fakt wyraźnie negatywny — analiza stosunku Donoso Cortésa do każdego jej aspektu nie pozostawia w tym względzie najmniejszych wątpliwości. Państwową rację stanu przeciwstawia własnej racji bytu, która jest charakterystyczna dla ruchów rewolucyjnych odznaczających się narracją negacji: absolutnego zaprzeczenia i niechęci wobec każdej formy władzy wyrastającej z tradycji, a także prawa boskiego i ludzkiego. Jak słusznie podnosi Frédéric Morgan, negacja ta jest w pełnym wymiarze destrukcyjna z natury dla porządku teologicznego, politycznego, społecznego oraz moralnego ${ }^{16}$.

Z nakreślonego przez kontrrewolucjonistę obrazu wyłania się pewien dowiedziony później truizm, według którego społeczeństwa podatne na wpływ nowych, obrazoburczych prądów ideologicznych prędzej czy później padną ofiarą buntu. W Mowie o dyktaturze markiz de Valdegamas zaznacza, że rewolucje są chorobami nękającymi ludy bogate, a nade wszystko ludy wolne ${ }^{17}$. Należy jednak w tym zakresie myśl hiszpańskiego zachowawcy doprecyzować, wskazując, że o ile podatność na nowe doktryny zwiększa możliwość wystąpienia buntu, o tyle nie zawsze czynnikami przyspieszającymi go będą bogactwo i wolność, jakkolwiek w wypadku burbońskiej Francji podstawą zrywu była w znacznej mierze niechęć do bogactw monarszych i ukazujące się na horyzoncie widmo wolności.

Ancien régime słabł w oczach, a Donoso Cortés obwieszczał wtargnięcie mas w konflikty nękające Europę. Nowe formy rewolucyjne niszczą zastane prawa i obyczaje utrzymujące oraz umacniające istniejący dotąd ład, który nie wytrzyma pod ich naporem będącym rezultatem buntu czyniącego wszystko, co dotychczasowe, wrogim i przestarzałym ${ }^{18}$. Materializm i chaos nowoczesnego świata sprawiają, że ów bunt zyskuje w opisywanym reakcjoniście zagorzałego krytyka. Myśliciel posługuje się określeniem ,śmierć cywilizacji” odnoszącym się do

miastach Europy. W Paryżu demagogia zdeptała skarby cywilizacji europejskiej, w Wiedniu pogrążyła majestat cesarski, w Berlinie natomiast poważnie nadwyrężyła znakomitości świata filozofii. Nauka, jaką kontrrewolucjonista próbuje zatem przekazać, ukazuje się w sposób przejrzysty, stanowiąc ostrzeżenie, że dekompozycja dotychczasowego porządku nie zagraża wyłącznie Burbonom, ale również Habsburgom, Hohenzollernom i innym dynastiom europejskim.

${ }^{16}$ F. Morgan, op. cit., s. 636. Destrukcyjność rewolucji ujawniająca się na każdej z wymienionych płaszczyzn jest absolutna, w związku z czym, w nomenklaturze pojęciowej hiszpańskiego reakcjonisty, stanowi zło absolutne.

17 J. Donoso Cortés, Mowa o dyktaturze, [w:] O katolicyzmie..., s. 303.

18 F. Morgan, op. cit., s. 637. W obliczu takiej konstatacji myśliciel kontynuuje, że potrzebna jest kontrrewolucja będąca tej rewolucji przeciwieństwem, mająca za zadanie obronę i utwierdzenie ładu, harmonijne uporządkowanie relacji duchowych i społecznych. Rozumienie kontrrewolucji będzie zatem tożsame z tym, które przedstawiał Joseph de Maistre, pisząc, że „odnowienie monarchii nazywające się kontrrewolucją nie będzie rewolucją przeciwną, ale przeciwieństwem rewolucji”. Zob. J. de Maistre, Considérations sur la France, Paris 1936 [1796], s. 164. Zbieżność w rozumieniu kontrrewolucji nie jest przypadkowa. De Maistre uczynił je bowiem właściwymi tradycjonalizmowi francuskiemu, z którym poglądy hiszpańskiego reakcjonisty pozostają zgodne. 
wyglądu porewolucyjnego świata i przekonuje, że w takiej sytuacji nie można postąpić inaczej, jak tylko podporządkować się służbie Kościołowi i Ojczyźnie reakcyjnej ${ }^{19}$. Postawa ta wymaga otwartości ducha oraz wielu wyrzeczeń. Wyróżnia się ona uniwersalnym charakterem przez niepoprzestawanie na obronie interesów pewnej grupy społecznej. Jak można się przekonać, analizując historię reakcyjnej myśli politycznej, nie była to tylko zapowiedź działań, ale starannie wdrażany program odparcia siły, której nie dało się już wyeliminować. Donoso Cortés nie bronił sprawy pojedynczych ofiar rewolucji, lecz interesu tysiącletniej cywilizacji starszej od każdej rewolucyjnej doktryny ${ }^{20}$.

Nie mogąc pogodzić się z nieuchronnym postępem wymuszającym zmianę wizerunku znanego mu świata, choć uświadamiając sobie jego nadchodzący trumf, hiszpański uczony wykorzystuje swoje talenty, aby z jednej strony proces ten opóźnić, z drugiej natomiast sprawić, by śmierć cywilizacji nie była całkowita lub, w najgorszym wypadku, by zapamiętano usilne próby walki.

Kwestię, dlaczego rewolucja wymaga od zachowawcy stanowczej reakcji, myśliciel rozstrzyga w sposób klarowny. Rewolucjoniści stawiają na piedestale fałszywych bogów, złą kopię najwyższego Stwórcy urzeczywistniającego ugruntowany porządek społeczny. Hiszpan wskazuje, że Bóg stał się człowiekiem dla nas, by zbudować nasz świat, a nie niszczyć, tymczasem w momencie, gdy Jego miejsce zastąpiły szlachetnie brzmiące idee wolności, równości i braterstwa, rolę porządku zastąpiła jego destabilizacja i niepohamowana żądza zmian. W takiej sytuacji, gdy nie ma zakotwiczenia w bycie ponadczasowym, transcendentnym, wszyscy ci, którzy byli sprawcami rewolucji, w przyszłości staną się ofiarami kolejnej. Nie będą potrafili obronić zdobytej pozycji, ulegając w pewnym momencie nakręconej przez samych siebie machinie przemian entuzjastycznie przyjętej przez przedstawicieli idei buntu w samym sercu cywilizacji ${ }^{21}$.

19 Ibidem, s. 638. Z podporządkowania się wizji przedrewolucyjnego ładu opartego na monarchicznym kształcie ustrojowym wzmocnionym nauczaniem Kościoła katolickiego wynika konieczność podjęcia walki ze zrywem rewolucyjnym. Sam myśliciel jest do tej walki nastawiony pesymistycznie. Twierdzi, że klęska to coś nieuniknionego, ale tylko w działaniu można zminimalizować katastrofę i najbardziej bezpośrednie przejawy zła. Walka jest obowiązkiem moralnym prawdziwego katolika, patrioty i przykładnego prawnika służącego królowi. Upadek, jak twierdzi markiz de Valdegamas, to zatem sprawa nieuchronna, ale bierność będzie jeszcze większym złem moralnym. Zob. J. Donoso Cortés, L'Église et la Révolution, s. 349.

${ }^{20}$ Ibidem, s. 644.

${ }^{21}$ Ibidem, s. 639. Z przedstawionej konstatacji wyłania się pewne przesłanie. Jakkolwiek tryumf rewolucji wydaje się nieunikniony, to jej przedstawiciele nie mają zdolności wykreowania stanu na tyle dobrego, by mógł się on równać z ładem przedrewolucyjnym. Gdy zachęceni rewolucyjnymi hasłami wrogowie dawnego porządku uświadomią to sobie, będą próbowali jedynie utrzymać własne dziedzictwo, co z kolei sprawi, że skupią na sobie zawiść innych, których zaufanie w stosunku do wprowadzonych przemian osłabnie. W społeczeństwie pojawią się zatem kolejne oddolne tendencje mające na celu obalenie następnej formy władzy. Zjawisko to opisał dokładnie Vilfredo Pareto, tworząc swoją „teorię krążenia elit”, która zdaje się z poczynionymi 
Być może głównie świadomość takiego stanu rzeczy skłoniła hiszpańskiego zachowawcę do tego, aby nie pozostawać biernym i wykazać siłę będącego w defensywie ancien régime'u.

\subsection{Krytyka liberalizmu, racjonalizmu i socjalizmu}

Rewolucja francuska kojarzona jest z wielkim zwycięstwem idei liberalnych, które miały odtąd wpływać na kształt rozwijającego się świata, w tym głównie racjonalizmu szczególnie przez Donoso Cortésa potępianego. Reakcjonista swoją niechęć uzasadnia kilkoma negatywnymi w jego mniemaniu założeniami tych doktryn, leżącymi u ich podstaw i wpływającymi na postrzeganie świata przez kolejne pokolenia. W pierwszej kolejności poddaje gruntownej analizie powszechne rozumienie wolnej woli, wykazując, że jest ono fałszywe. Często spotykamy się bowiem z przekonaniem, z którego wynika, że w granicach wolnej woli istnieje możność dokonania wyboru pomiędzy dobrem a złem przyzywającymi nas z przeciwległych stron. Tymczasem, jak tłumaczy markiz de Valdegamas, rzecz ma się zupełnie inaczej, a przyjmowanie takiej wersji za pewnik mogłoby doprowadzić do dwóch absurdalnych konstatacji, przy czym jedna dotyczyć będzie człowieka, a druga Boga 22 .

W odniesieniu do pierwszej Hiszpan argumentuje, że człowiek doskonali się, wybierając dobro, jednakże przez sam fakt doskonalenia się traci swoją wolność z uwagi na to, że świadomie podporządkowuje się władzy tej strony, którą wybrał — w tym przypadku dobra. Równowaga między skrajnymi rozwiązaniami słabnie w miarę zbliżania się do któregoś z nich, w ten sam sposób niweluje się zakres wolności będącej w dyspozycji jednostki. W założeniu racjonalistycznym pełna wolność wyboru jest stanem doskonałym, przy czym stwierdzenie to, jak dowodzi zachowawca, jest z natury swej sprzeczne, gdyż tracimy wolność, stając się doskonale dobrymi bądź doskonale złymi, a doskonała wolność nigdy nie występuje z uwagi na to, że nie jest to możliwe. Ukazany paradoks polega więc na tym, że jednostka, która jest wolna i powinna być z uwagi na to doskonała, nie zachowa wolności, jeżeli nie zrezygnuje ze swojej doskonałości, oraz jednocześnie nie będzie doskonała, gdy nie zrezygnuje z bycia wolną ${ }^{23}$.

W wypadku konsekwencji odnoszącej się do Stwórcy, zakłada ona, że jeśli nie ma w Nim przeciwstawnych wezwań (a tych być nie może ze względu na przyrodzoną doskonałość Boga), to nie ma w Nim wolności wyboru — podstawy wszelkiej wolności. Bóg jest zatem doskonały, ale już nie dysponuje wolnością 24 . Można też zadać sobie pytanie, kto miałby ograniczać wolność Istoty Wszech-

konkluzjami w pełni zgodna. Zob. V. Pareto, Uczucia i działania. Fragmenty socjologiczne, przeł. M. Dobrowolska, M. Rozpędowska, A. Zinserling, Warszawa 1994.

22 J. Donoso Cortés, Esej o katolicyzmie..., s. 70-71.

23 Ibidem, s. 70.

24 Ibidem, s. 71. 
mogącej. Podobnie, czy można ją ograniczyć, jeżeli nikt nie wzniesie się ponad Jej możliwości oraz czy będzie wolna, jeżeli oddali się od swej doskonałości. Dostrzegamy wobec tego, że między takim rozumieniem wolności a naturą Boga tkwi oczywista sprzeczność. Złożony proces myślowy przedsięwzięty przez Donoso Cortésa służy nie tylko ukazaniu absurdalności ugruntowanego w postawie ateistycznej i materialistycznej racjonalistycznego pojmowania wolnej woli, ale przede wszystkim podkreśleniu szaleństwa, jakim jest odrzucenie obdarzonego walorem porządkującym rzeczywistość polityczną dogmatu katolickiego ${ }^{25}$.

Wywodząc, że w zarysowanej konwencji interpretacyjnej wolność jest niedoskonała ze względu na to, że opiera się na wykreowaniu możności wyboru między posłuszeństwem Bogu z jednej strony a buntem przeciw niemu z drugiej, to przyznanie człowiekowi możliwości jego dokonania jest niczym innym, jak utworzeniem prawa do zmieniania bożego dziedzictwa, czyli innymi słowy zastępowania ładu nieładem, harmonii chaosem i wreszcie dobra złem $^{26}$. Posługując się pojęciem porządku światowego, politycznego, duchowego, moralnego, Donoso Cortés odsłania kruchość społeczeństwa liberalnego, a przede wszystkim jego pozorną neutralność. Należy zauważyć, że kryje się za tym nadto sukcesywnie podnoszony prymat ładu absolutnego ${ }^{27}$.

Juan Donoso Cortés zarzuca liberalizmowi również jego wyniosłość opartą, jak stwierdza, na pysze i niewiedzy urzeczywistniających się w przekonaniu, że nie ma on nic wspólnego z teologią. Tymczasem, co już zasygnalizowano, nie ma dla markiza de Valdegamas jakiejkolwiek rzeczy czy ideologii, do której teologia by się nie odnosiła. Kluczowe znaczenie w tym zakresie ma niezrozumienie przez szkołę liberalną ścisłego związku między rzeczami boskimi a ludzkimi oraz bliskiego pokrewieństwa między sprawami politycznymi, społecznymi i religijnymi ${ }^{28}$.

Myśliciel wydaje się odróżniać liberalizm od racjonalizmu, wskazując, że ten drugi będzie odmianą bardziej skrajną, bo w niej pozorna neutralność światopoglądowa zmierzać będzie powoli $\mathrm{w}$ stronę ateizmu ${ }^{29}$. Wniosek taki można

25 Ibidem, s. 78. Kontrrewolucjonista wzmacnia swoje stanowisko przez przeprowadzenie próby pewnej gradacji, gdzie racjonalizm cechuje zaprzeczenie, w którym wszystko jest negacją, fałszem, absurdem i sprzecznością. Odmiennie ocenia twierdzenie katolickie - tutaj każdy element jest prostotą, logiką, klarownym rozwiązaniem.

${ }^{26}$ Ibidem, s. 120.

27 F. Morgan, op. cit., s. 652. Na uwagę zasługuje kontynuacja widocznego już w dyskursie kontrrewolucyjnym schematu konsekwentnego uwidaczniania sprzeczności między rozumem oświeceniowym a wiarą, co zaowocowało przyporządkowaniem markiza de Valdegamas do przedstawicieli intelektualnej kontrrewolucji. Zob. A. Wielomski, Upadek Europy i rzady autorytarne w myśli Juana Donoso Cortésa, „Pro Fide, Rege et Lege” 1997, nr 1, s. 19-22.

28 J. Donoso Cortés, Esej o katolicyzmie..., s. 130. Uznawanie za marginalne kwestii związanych $\mathrm{z}$ teologią $\mathrm{w}$ żadnym wypadku nie sprawia, że nie występuje ona w danym programie politycznym czy systemie wartości.

29 Jakkolwiek odwołując się do twórczości hiszpańskiego kontrrewolucjonisty, pogląd taki wydaje się uzasadniony, to w literaturze można znaleźć również stwierdzenie, że racjonalizm 
wywieść z analizy Eseju o katolicyzmie, liberalizmie i socjalizmie, w którym stwierdza, że według szkoły liberalnej problem dobra i zła znajduje rozwiązanie w aspekcie rządu, ten zaś w kwestii legitymizacji władzy. Rząd prawowity wyklucza zło, nieprawowity natomiast je przyciąga. Rozstrzygając z kolei, czy dany rząd jest prawowity, czy uzurpatorski, liberałowie konkludują — chociaż zapewne nie w pełni świadomie - że prawowitymi są rządy ustanowione przez Boga, a uzurpatorskimi te, których nie oparto na boskich przykazaniach. Mimo iż prima facie wydaje się to sprzeczne $\mathrm{z}$ dotychczasowymi ustaleniami, dla kontrrewolucjonisty ten wniosek jest w pełni oczywisty. Zakładając, że liberalizm sam w sobie nie jest ani ateistyczny, ani katolicki, chociaż nieuchronnie zmierza w stronę ateizmu jako konsekwencja rewolucji, to zauważyć należy, iż pozostaje deistyczny. W ocenie Donoso Cortésa deizm od katolicyzmu w kontekście oceny formy ustrojowej różnić się będzie tym, że podczas gdy ten pierwszy widzi w Bogu najwyższą władzę konstytutywną i aktualną, drugi dostrzega w Nim jedynie władzę konstytutywną, tę aktualną powierzając świeckim organom władzy państwowej. W zupełności jest to jednak wystarczające, aby za prawowity uznać rząd powołany przez Boga $^{30}$. Z takiego rozumowania wyłania się wada liberalizmu pozwalająca wnioskować, że nie utrzyma się on długo. Ów kierunek polityczny jest dla rewolucyjnej destabilizacji zaledwie etapem przejściowym do całkowitego zanegowania ancien régime’u. Zostanie pochłonięty przez kolejne doktryny odrzucające nawet podejście deistyczne i przyjmujące nastawienie ateistyczne, czyli odmawiające Bogu jakiejkolwiek władzy ${ }^{31}$.

Czynnikiem łączącym liberalizm i racjonalizm było przeczenie solidarności rodzinnej, a także głoszenie zdolności wszystkich ludzi do piastowania jakichkolwiek godności publicznych, co oznaczało jednoczesną negację oddziaływania przodków na potomków i dziedziczenia określonego zespołu cech przygotowujących do wypełniania zadań wyznaczanych niejednokrotnie przez rodzinne tradycje. Prowadziło to również do gloryfikowania bogactwa, które zajęło miejsce szlachetności, wydającego się bardziej uprawnionym do ulokowania na piedestale od znienawidzonych arystokratów ${ }^{32}$.

stanowi wyraz umysłowy liberalizmu, co oznacza, iż będzie z nim nierozłączny i każdorazowo doprowadzi finalnie do postawy ateistycznej. Por. J. Bartyzel, Juan Francisco María da Salud Donoso Cortés, http://www.legitymizm.org/ebp-juan-francisco-maria-da-salud-donoso-cortes (dostęp: 6.10.2020).

30 J. Donoso Cortés, Esej o katolicyzmie..., s. 133-134.

31 Ibidem, s. 134. Z tego opisu wynika, że doktryną gorszą od liberalizmu jest socjalizm, który narodził się po nim. Jednocześnie również i on nie powstałby bez rewolucji. W ostatecznej konfrontacji liberalizm zniknie, a pozostaną katolicyzm i socjalizm. Swoje racje Donoso Cortés ilustruje następującymi słowami: „w budzącym trwogę dniu, gdy pole bitwy zapełni się oddziałami katolickimi i oddziałami socjalistycznymi, nikt nie będzie wiedział, gdzie jest liberalizm”. Ibidem.

32 Ibidem, s. 198-203. Z nakreślonego przez Donoso Cortésa obrazu liberalizmu wynika przerwanie ciągłości w czasie, kontynuacji chwały, zniesienie obecnej w rodzinie miłości, a w państwie patriotyzmu. Znamienna jest także niwelacja społeczności domowej i politycznej. 
Liberalizm skupiał się niemal wyłącznie na kwestiach rządu, które w porównaniu z problemem porządku religijnego i społecznego nie miały większego znaczenia. Doglądanie jedynie swej obecnej władzy uczyniło zeń szkołę zepsutą i nieświadomą zagrożeń odnoszących się do niego samego. Z jednej strony w dalszym ciągu funkcjonował bowiem znaczący, chociaż poważnie osłabiony, dogmat katolicki, z drugiej natomiast w boju o europejskie umysły swoją obecność zaczął zaznaczać socjalizm — druga obok liberalizmu spośród herezji czasów nowożytnych wymienianych przez Donoso Cortésa ${ }^{33}$.

Socjalizm w oczach zachowawcy stanowi poważne zagrożenie. W przeciwieństwie do liberalizmu przechodzi niemal natychmiast do problemów wielkich, szykując alternatywne, ostateczne i decydujące rozwiązanie usytuowane po przeciwnej stronie od tego proponowanego przez zwolenników ancien régime'u - w tym tkwi wyższość szkół socjalistycznych nad liberalnymi ${ }^{34}$. Przewaga ta widoczna jest jednak przede wszystkim w wykreowaniu pewnej formy teologii pozytywnej, będącej jednakże „teologią szatańską” ze względu na swój niszczycielski charakter w stosunku do ładu absolutnego. Nieporównywalnie potężniejsza od sceptycyzmu i krótkowzroczności liberalizmu jest natomiast nawet teologia socjalistyczna przeciwna katolickiej w odniesieniu do jej powszechności i roli przez nią spełnianej35. Markiz de Valdegamas na swój sposób definiuje także socjalizm, wykazując jego różnice w zestawieniu z liberalizmem: „Wszystkie szkoły socjalistyczne z filozoficznego punktu widzenia są racjonalistyczne; z punktu widzenia politycznego republikańskie; z religijnego punktu widzenia - ateistyczne. Racjonalizm zbliża je do szkoły liberalnej, od której odróżnia go ateizm i republikanizm" ${ }^{36}$. Zważając na naturę problemów, sposób ich formułowania oraz rozwiązywania, stwierdza, że przewyższają one liberalizm.

W ocenie hiszpańskiego zachowawcy doktryny socjalistyczne wychodzą z założenia, że zło istnieje w społeczeństwie lub rządzie, a nierzadko w obu. Uznając to twierdzenie za słuszne, owe doktryny przekonują, że jedyne, co należy z tym zrobić, to definitywnie wywrócić ład polityczny lub społeczny. Sam człowiek znajduje się natomiast na marginesie tych rozważań; próba przekształcenia go nie jest bowiem ani konieczna, ani dogodna, wręcz przeciwnie - całkowicie szkodliwa i absurdalna ${ }^{37}$. Co zachowawcę zdumiewa, to kolektywne oswajanie

33 J. Bartyzel, Juan Francisco Maria da Sadud...

34 J. Donoso Cortés, Esej o katolicyzmie..., s. 136.

35 Ibidem, s. 136-137. W stosunku do tak postawionego problemu myśliciel kontynuuje, że potężniejsza od zwątpienia teologia szatańska będzie musiała zmierzyć się z uosabiającą boskość teologią katolicką. Mimo dotychczas odbieranego na gruncie analizy Eseju o katolicyzmie... pesymizmu autora w tym zakresie ujawnia się jego pełne nadziei przekonanie, że w wojnie tej, której stawką jest rząd dusz w Europie, a w przyszłości być może również na świecie, teologia katolicka zdecydowanie zatryumfuje.

36 Ibidem, s. 140.

37 Ibidem, s. 154. 
się z chorobą umysłową, której przejawem jest wiara w dobro i szlachetność człowieka przy jednoczesnym dostrzeganiu zła pochodzącego od władzy i Boga. Jak wskazuje Jacek Bartyzel, niszcząca siła tej dewiacji okazała się stokrotnie groźniejsza od tchórzliwych wątpliwości właściwych liberałom, zwłaszcza w sytuacji połączenia typowego socjalistycznego materializmu i ateizmu z despotyczną władzą $^{38}$. Ten sam uczony dodaje, że socjalizm bierze swoją siłę z nieznajdującej żadnych zahamowań demagogii, która doprowadzi do powstania samoubóstwiającego się społeczeństwa totalnego. Zauważył to też Donoso Cortés, konstatując, że potrzeba oddawania czci ma charakter bezwzględny, socjaliści natomiast, jako ateiści, tylko się pogrążają. Wykluczając bowiem możliwość wielbienia Boga, szukają innej drogi służącej do zaspokojenia tej potrzeby i znajdują rozwiązanie w oddawaniu czci człowiekowi, czyniąc bogów z ludzi ${ }^{39}$.

W perspektywie sformułowanego w ten sposób problemu przedstawiona została fundamentalna różnica między socjalistycznym a katolickim światem wartości. Odnosi się ona do istoty zła oraz sposobu jego wyeliminowania. Podczas gdy katolicyzm przekonuje, że zły jest człowiek, dlatego potrzebuje on odkupienia ze strony Boga, socjalizm wyraża stanowisko, które uzasadnia twierdzeniem o konieczności pokonania przez człowieka zła tkwiącego w społeczeństwie ${ }^{40}$. Reakcjonista wskazuje, że w myśli socjalistycznej nie występują właściwe prawdzie absolutnej logika i konsekwencja. Przymioty te powinny w jego ocenie uzupekniać wszystkie zabiegi argumentacyjne w dyskursie naukowym. Socjalizm, nie mogąc ich spełniać, ulokowany jest więc poza tym dyskursem. Przez odmówienie szkołom socjalistycznym logiki i konsekwencji Donoso Cortés wywodzi ich sprzeczność oraz niejednolitość głoszonych poglądów, co spowoduje wewnętrzne konflikty w gronie zwolenników omawianej doktryny. Taki stan rzeczy prowadzi nieuchronnie do odrzucania konsekwencji swoich własnych zasad, które nie mogąc być urzeczywistniane, zostaną uznane za fałszywe.

Oskarżeń tych nie pozostawiono samych sobie. Na ich poparcie zaprezentowano przykład zadowolenia się odrzuceniem solidarności domowej (co związane jest

38 J. Bartyzel, Juan Francisco Maria da Sadud...

39 J. Donoso Cortés, Esej o katolicyzmie..., s. 154-155. Potwierdzeniem tego spostrzeżenia w oczach reakcjonisty wydają się santsimonizm i fourieryzm, które zasadność swego istnienia i zaspokajania potrzeby oddawania czci widzą w wykazaniu jedności między duchem i ciałem. Odrzucając ugruntowany wcześniej dualizm polityczny, społeczny i naukowy, zanegowano antytetyczną naturę człowieka. Sprawiło to, że socjaliści zyskali w oczach hiszpańskiego autora określenie „bandy komediantów”.

40 Ibidem, s. 158. Kreślona przez Donoso Cortésa panorama doczesności odnosząca się do katolicyzmu wydaje się bardzo prosta i ułożona według utrwalonego schematu, z którego wynika, że człowiek czyni dzieła ludzkie, a Bóg odpowiednio boskie. W socjalizmie natomiast pierwiastkiem właściwym Stwórcy obdarzony został człowiek. Hiszpan, zestawiając z sobą te spostrzeżenia, konkluduje, że porzucenie katolicyzmu dla socjalizmu jednoznaczne będzie z porzuceniem tego, co jest oczywiste, a zarazem tajemnicze, na rzecz zjawiska absurdalnego i tajemniczego. 
między innymi z fourieryzmem), przy czym właściwą konsekwencją zanegowania idei solidarności w ogóle byłoby również odrzucenie społeczności politycznej ${ }^{41}$. Zarzut ten wzmocniony został poczuciem nieumiejętnej obserwacji rzeczywistości politycznej i społecznej przez środowiska hołdujące myśli socjalistycznej, co z powodzeniem mogłoby odnieść się również do krytykowanego przez konserwatystę liberalizmu. Stosunek Donoso Cortésa do tej kwestii najlepiej zobrazować przez przytoczenie fragmentu jego wywodu:

Wierzyć w równość wszystkich ludzi, widząc ich wszystkich nierównymi; wierzyć w wolność, widząc instytucję poddaństwa we wszystkich krajach; wierzyć, że wszyscy ludzie są braćmi, gdy historia uczy, że wszyscy są nieprzyjaciółmi; wierzyć, że dla wszystkich narodzonych istnieje wspólne archiwum klęski i chwały, kiedy nie sposób dostrzec nic poza chwałami i klęskami indywidualnymi; wierzyć, że odnoszę siebie do ludzkości, kiedy wiem, że odnoszę ludzkość do siebie; wierzyć, że ta sama ludzkość jest moim centrum, kiedy to ja czynię się centrum wszystkiego; a na koniec wierzyć, że powinienem wierzyć w te rzeczy, kiedy ci, którzy mi je proponują jako przedmiot wiary, twierdzą, że nie powinienem wierzyć niczemu poza własnym rozumem, który przeczy wszystkim proponowanym mi rzeczom, co jest tak wielką niedorzecznością, tak niepojętą aberracją, że staję wobec nich jak oniemiały i pozbawiony zmysłów ${ }^{42}$.

Narracja negacji właściwa, jak już zasygnalizowano, liberałom, została przyjęta w stopniu znacznie wyższym przez socjalistów. Juan Donoso Cortés dowodzi niestrudzenie, że w przypadku socjalizmu każde zaprzeczenie skierowane do jakiejkolwiek instytucji ancien régime'u doprowadzi do nihilizmu. Retoryka socjalistyczna rozpoczyna swoje wywody od zanegowania grzechu, a z odrzucenia go wynika cała seria kolejnych negacji. Stwierdzając, że nie istnieje grzech, jak również możliwość jego dokonania, nieuchronnie zaneguje się wolność człowieka, wszak wolnym w ocenie markiza de Valdegamas może być jedynie ten, kto ma zdolność do grzeszenia oraz przemiany swojej duszy. W dalszej kolejności z zaprzeczenia wolności wynika kontestacja odpowiedzialności. Jeżeli nie można natomiast przypisać winy w wyniku uznania czyjejś odpowiedzialności, niemożliwe będzie wymierzenie mu kary. Odtrącenie kary będzie oznaczało już tylko całkowitą negację najpierw rządu boskiego, a następnie rządów ludzkich. Przemieszczając się w dół po kolejnych szczeblach zarysowanej drabiny negacji, na sam koniec dojdziemy do nihilizmu ${ }^{43}$. Nie można zejść już niżej. Pogrążenie się w poczuciu braku celowości jest ostatecznym i jednocześnie najgroźniejszym stadium zdobywania przestrzeni życiowej przez myśl socjalistyczną, czemu, jak przekonuje hiszpański kontrrewolucjonista, należy przeciwdziałać, wykorzystując nadzwyczajne środki. Wniosek ten, uzupełniany dotychczas poczynionymi spostrzeżeniami, to zaledwie uwertura przed wielką operą, jaką jest koncepcja dyktatury w imię ładu.

\footnotetext{
41 Ibidem, s. 204-205.

42 Ibidem, s. 206-227.

43 Ibidem, s. 226.
} 


\section{Dyktatura — rozwiązanie kontrrewolucjonisty}

Czwarty dzień stycznia roku pańskiego 1849 to data szczególna z perspektywy przedstawiania myśli politycznej Donoso Cortésa. Tego dnia deputowany do hiszpańskich Kortezów rozwija problematykę, która w zaczątkowej formie pojawiła się w ultramontańskim manifeście de Maistre'a - O papież $u^{44}$. Stanowcza obrona postawy decyzjonistycznej służącej odbudowie ładu absolutnego była uświadomioną koniecznością. W Mowie o dyktaturze parlamentarzysta podkreśla, że rozwiązania usankcjonowane w wolności i legalizmie powinny znaleźć zastosowanie, kiedy są wystarczające, w przeciwnym wypadku uwagę należy skierować na dyktaturę. Makiawelistyczna retoryka odzwierciedla się w przeświadczeniu markiza de Valdegamas twierdzącego, że w pewnych okolicznościach, takich jak te dające się zaobserwować w dziewiętnastowiecznej Hiszpanii, dyktatura jest rządem dobrym, korzystnym i racjonalnym, do tego zdolnym do obronienia się zarówno w teorii, jak i praktyce ${ }^{45}$. Sygnalizacja nieodzowności dyktatury nie jest przy tym formułowana przez szaleńca marzącego o rządzie lubującym się w podporządkowywaniu życia społeczno-politycznego swoim grymasom. Wręcz przeciwnie, argumentacja Donoso Cortésa wydaje się spójna i zdroworozsądkowa. Uczony podkreśla, że w obliczu kryzysu dawnego ładu społeczeństwo nie stanęło przed wyborem pomiędzy wolnością a dyktaturą. Gdyby ów wybór istniał, sam reakcjonista optowałby za wolnością. Rzecz w tym, jak kontynuuje, że wolności już nie ma. Rządy konstytucyjne pozostały w jego oczach zaledwie namiastką skutecznej władzy, pustą skorupą, szkieletem bez życia ${ }^{46}$.

Płynące z przemówienia zachowawcy przekonanie o zanikaniu wolności po rewolucji wbrew, jak mogłoby się wydawać, zamierzeniom środowisk, które ów zryw zainicjowały, prowadzi do wniosku, że niezależnie od jego propozycji dyktatura stanowi pewnego rodzaju konieczność dziejową. Jednakże, co zauważa Donoso Cortés, od nas samych zależy rodzaj wybranej dyktatury. Zachowując bierność, pozwolimy na rozprzestrzenianie się dyktatury insurekcji, z kolei dążąc do obrony porządku, zdecydujemy się na tymczasową dyktaturę rządu. Pierwsza ma charakter oddolny, określano ją mianem dyktatury sztyletu. Druga natomiast

44 Dzieło francuskiego kontrrewolucjonisty okazało się dla Donoso Cortésa niezwykle inspirujące. Hiszpan natomiast wpłynął na rozwój decyzjonistycznej myśli Carla Schmitta. Zob. R. Skarzyński, Od chaosu do tadu. Carl Schmitt i problem tego, co polityczne, Warszawa 1992, s. 57. W odniesieniu do problemu dyktatury uwydatnia się aspekt łączący markiza de Valdegamas z niemieckim teoretykiem. Obaj wyrażali przekonanie, że dotychczasowe uprawomocnienie sakralne nie jest dla nowożytnego człowieka wystarczające, jeżeli chodzi o utrzymanie starego porządku. Zob. A. Wielomski, Od grzechu do apokatastasis. Historiozofia Josepha de Maistre'a, Warszawa 2011, s. 12. Nie zmienia to jednak faktu, że dyktatura opisywana przez markiza de Valdegamas funkcjonować powinna w sposób zgodny z nauką katolicką. Por. F. Suarez Verdeguer, Introducción a Donoso Cortés, Madrid 1964, s. 66.

45 J. Donoso Cortés, Mowa o dyktaturze, s. 297-298.

46 Ibidem, s. 316. 
jest odgórna i została przedstawiona jako dyktatura szabli. W oczach mówcy to właśnie dyktatura szabli, jako jaśniejsza, szlachetniejsza i czystsza, powinna zostać wybrana ${ }^{47}$.

Nawiązując do poprzednich konkluzji, stwierdzić można ponad wszelką wątpliwość, że koncepcja dyktatury hiszpańskiego reakcjonisty nakazuje wręcz postrzeganie jej w konwencji niezbędnego narzędzia, którego przejściowe zastosowanie pozwoli przywrócić naruszony przed laty porządek. By plan się powiódł, nieodzowna jest pomoc autorytetu wzbudzającego szacunek. Idea autorytetu samego w sobie wywodzi się naturalnie z katolicyzmu - co kontrrewolucjonista artykułuje niemal w każdym swoim przemówieniu - a jako że został bezpośrednio ustanowiony przez Boga, cechuje go nieomylność i niezmienność ${ }^{48}$. W obliczu rewolucji, mając w sercu dogmat katolicki, walka z jej niekorzystnymi następstwami jest możliwa wyłącznie przez dyktaturę. Niepowstrzymaną dotąd ekspansję przewrotową zniweczyć może już bowiem tylko ta ostateczna ucieczka, brana pod uwagę, co warto podkreślić, ze względu na brak możliwości zastosowania innych instancji, bezpowrotnie już utraconych ${ }^{49}$. Dyktatura ma jeszcze jeden cenny walor: pozwala zakończyć parlamentarny impas decyzyjny i skupić się na ocaleniu kraju, za co Donoso Cortés zdobywał pochwały również ze strony rządzącego wówczas generała Ramóna Maríi Narvaéza ${ }^{50}$.

Dyktatura w porządku politycznym utożsamiona została $\mathrm{z}$ cudowną interwencją, rozwiązaniem zakorzenionym w ładzie boskim. Zawiera w sobie obecność koniecznych, naturalnych pierwiastków, które rewolucja próbuje rozproszyć, aby szybciej rozsmakować się w swoim zwycięstwie ${ }^{51}$. Tryumf społecznego przewrotu związany jest z odwracaniem się od bożego porządku, co myśliciel wyczerpująco uzasadnia w Eseju o katolicyzmie, liberalizmie $i$ socjalizmie. Zanim jednak swoje wnioski opisał w tej przełomowej pracy, wyraził pogląd podstawowy z perspektywy analizy dyktatury. Mianowicie przekonywał parlamentarzystów, że istnieją tylko dwa rodzaje wędzideł oddziałujących na ludzkość: religijne i polityczne. Zagadnienie to można rozpatrywać na przykładzie termometrów, pomiędzy którymi występuje następująca zależność: wzrost słupka rtęci na termometrze religijnym jest jednoznaczny ze spadkiem wskaźnika na termometrze politycznym i odwrotnie. Juan Donoso Cortés perorował, iż jest to prawo ludzkości oraz

47 Ibidem, s. 316-317.

48 F. Morgan, op. cit., s. 646. Harmonia relacji międzyludzkich nastąpić może jedynie w społeczeństwie katolickim, do czego przekonuje Donoso Cortés. Chrystus sprawuje bowiem rządy za pośrednictwem swojego wikariusza obdarzonego świętą władzą. Hiszpan powtarza również za de Maistre’em, że Kościół sprawuje polityczny autorytet nad narodami. Jego suwerenność przejawia się w osobie papieża jednoczącego Kościół z chrześcijaństwem i różnorodnością narodów katolickich.

49 Ibidem, s. 648.

50 J.T. Graham, Donoso Cortés: Utopian Romanticist and Political Realist, Colombia 1974, s. 224.

${ }^{51}$ F. Morgan, op. cit., s. 651. 
historii $^{52}$, a uważna analiza dziejów minionych jednoznacznie dowodzi słuszności tej tezy. Starożytność okazała się okresem, w którym wędzidło religijne nie mogło być poluzowane ze względu na to, że jeszcze nie istniało. W takiej sytuacji swój szczyt osiągnął ucisk polityczny. W ten sposób narodziła się tyrania. Narodziny Chrystusa zaowocowały powstaniem hamulca religijnego prowadzącego do osłabienia siły politycznej ${ }^{53}$. Czynniki polityczny i religijny równoważą się wzajemnie. Przy obniżeniu temperatury religijnej zachodzi intrygujące dla reakcjonisty zjawisko, kiedy to nie ma jeszcze rządu, ale już potrzeba jego zalążka. Zjawisko to dało się zauważyć nawet we wspólnotach wczesnochrześcijańskich, gdzie nie było jeszcze prawdziwych urzędników, a już działali rozjemcy i polubowni sędziowie stanowiący zarodek każdego rządu ${ }^{54}$.

Zaprezentowanie wzajemnego oddziaływania aspektu politycznego i religijnego na sytuację polityczną, społeczną oraz pośrednio moralną prowadzi do konkretnego określenia potrzeby reakcji religijnej. Wzrost temperatury religijnej jest konieczny z uwagi na to, że wskaźnik polityczny podniesiony wówczas do granic możliwości zacznie natychmiast spadać, spontanicznie, bez zbrojnego wysiłku ludów. Pozwoli to na ponowny rozkwit wolności. Reakcja uzdrowienia religijnego to zatem jedyny możliwy ratunek przed ustabilizowaniem się obecnego kształtu politycznego cementującego upadek dawnego porządku. Czy ta reakcja jest w ogóle możliwa? Bez wątpienia, odpowiada Donoso Cortés. Do pytania dotyczącego jej prawdopodobieństwa w niedalekiej przyszłości odnosi się już niechętnie, pesymistycznie konkludując, że takiej szansy nie dostrzega ${ }^{55}$.

\section{Podsumowanie}

Postawa, którą przedstawia Juan Donoso Cortés, wyrasta z najświetniejszych tradycji francuskiego tradycjonalizmu, wzbogaca nurt zachowawczy w zachodnioeuropejskiej myśli konserwatywnej oraz tworzy chętnie komentowany przez badaczy zgłębiających tę problematykę aspekt. Konsekwentna, a zarazem stanowcza narracja nastawiona na pochwałę ładu absolutnego, krytyka zagrażających mu doktryn oraz finalnie sformułowanie propozycji walki z nimi celem odbudowy poważnie osłabionego porządku stanowią znak rozpoznawczy hiszpańskiego uczonego. W rozważaniach naukowych należy rzetelnie oraz wyczerpująco ustalić zasadność przypominania podstawowych kwestii podnoszonych przez markiza de Valdegamas i ich wartości w kwestii rozwoju dyskursu politycznego. Na podstawie przeprowadzonych powyżej refleksji będzie się ona odwoływać do tytułowej teologii politycznej oraz koncepcji dyktatury.

\footnotetext{
52 J. Donoso Cortés, Mowa o dyktaturze, s. 308-309.

53 Ibidem, s. 309.

54 Ibidem, s. 310.

55 Ibidem, s. 313.
} 
Cortésowską koncepcję teologii politycznej charakteryzuje walor porządkujący, który w znacznym stopniu rozwinął badania naukowe poświęcone zagadnieniu teologii politycznej w ogóle, czyniąc je bardziej przejrzystymi, a także żywotnymi w wieku XX, czego najlepszym przykładem są prace Carla Schmitta. Wyrastająca z rozważań zakorzenionych $\mathrm{w}$ teologii politycznej koncepcja dyktatury stanowi natomiast płynne przejście od pozycji tradycjonalistycznej do decyzjonistycznej, co w perspektywie długofalowych konsekwencji nie tylko przyczyniło się do powstania nowego nurtu konserwatywnego, lecz także umiejętnie dostosowywało zachowawczą metodykę postępowania do zagrożeń współczesności, które Donoso Cortés po upływie 60 lat od rewolucji mógł na nowo zdefiniować i precyzyjnie określić, opracowując zmodyfikowaną narrację walki z nimi. Rozważania odnoszące się do dyktatury w imię ładu przejął następnie i wzbogacił wspomniany już Schmitt, formułując w latach dwudziestych XX wieku koncepcję dyktatury prezydenta Rzeszy, która miała zapobiec przejęciu władzy w Republice Weimarskiej przez partie antysystemowe.

Zachowawców łączy jedno przekonanie: rozstrzygający wszelkie spory akt woli politycznego suwerena ma moc ustanawiania tudzież w wypadku myśliciela hiszpańskiego odrestaurowania ładu politycznego wyrastającego z chaosu przedpolityczności/rewolucyjnych idei. Konkluzja ta w pełni odkrywa przesłanie, jakie Juan Donoso Cortés zawarł w obrębie swoich spostrzeżeń. Reakcjonista utworzył doktrynę, która nie była zwykłym przejawem nostalgii za minionym porządkiem czy też pozbawioną podłoża ideologicznego negacją Wiosny Ludów. Przeciwnie, pozostawił po sobie system światopoglądowy świadczący o ciągłości myśli konserwatywnej, przygotowujący ją na nowe wyzwania, a te, jak umiejętnie przewidywał, zbliżały się nieuchronnie.

\section{Bibliografia}

\section{Literatura}

Bartyzel J., U źródel „,Syllabusa”. Donoso Cortés versus katolicy liberalni, „Arcana: Kultura, Historia, Polityka" 2009, nr 90 (6).

Beneyto J.M., Apocalipsis de la modernidad: El decisionismo politico de Donoso Cortés, Barcelona 1993.

Cammilleri R., Juan Donoso Cortés. Il padre del Sillabo, wstęp G. Baget Bozzo, Genova 1998.

Donoso Cortés J., L'Église et la Révolution, [w:] idem, Euvres de Donoso Cortés, t. 2, Paris 1862.

Donoso Cortés J., Esej o katolicyzmie, liberalizmie $i$ socjalizmie rozważanych $w$ ich fundamentalnych zasadach, [w:] idem, O katolicyzmie, liberalizmie i socjalizmie, przeł. M. Wójtowicz-Wcisło, Kraków 2017.

Donoso Cortés J., Mowa o dyktaturze, [w:] idem, O katolicyzmie, liberalizmie i socjalizmie, przeł. M. Wójtowicz-Wcisło, Kraków 2017.

Graham J.T., Donoso Cortés: Utopian Romanticist and Political Realist, Colombia 1974.

Maistre J. de, Considérations sur la France, Paris 1936 [1796]. 
Morgan F., Juan Donoso Cortés, obserwator rewolucji w Europie, [w:] Czarna księga rewolucji francuskiej, red. R. Escande, przeł. B. Biały et al., Dębogóra-Kraków 2015.

Pareto V., Uczucia i działania. Fragmenty socjologiczne, przeł. M. Dobrowolska, M. Rozpędowska, A. Zinserling, Warszawa 1994.

Pérez J., Histoire de l'Espagne, Paris 1996.

Proudhon P.-J., Zwierzenia rewolucjonisty, [w:] idem, Wybór pism, t. 1, Warszawa 1974.

Schmitt C., Teologia polityczna i inne pisma, przeł. M.A. Cichocki, Warszawa 2012.

Skarzyński R., Od chaosu do ładu. Carl Schmitt i problem tego, co polityczne, Warszawa 1992.

Suarez Verdeguer F., Introducción a Donoso Cortés, Madrid 1964.

Szlachta B., Między tym, co popularne, a tym, co zdrowe. Uwagi o krytykach (i koncepcjach) politycznych Donoso Cortésa, [w:] J. Donoso Cortés, O katolicyzmie, liberalizmie i socjalizmie. Wybór pism, przeł. M. Wójtowicz-Wcisło, Kraków 2017.

Trybusiewicz J., De Maistre, Warszawa 1968.

Viereck P., Conservatism: From John Adams to Churchill, Princeton 1956.

Wielomski A., Filozofia polityczna francuskiego tradycjonalizmu: 1796-1830, Warszawa 2013.

Wielomski A., Od grzechu do apokatastasis. Historiozofia Josepha de Maistre'a, Warszawa 2011.

Wielomski A., Upadek Europy i rzady autorytarne w myśli Juana Donoso Cortésa, „Pro Fide, Rege et Lege" 1997, nr 1.

Wielomski A., W poszukiwaniu Katechona. Teologia polityczna Carla Schmitta, Radzymin 2017.

\section{Źródła internetowe}

Bartyzel J., Juan Francisco María da Salud Donoso Cortés, http://www.legitymizm.org/ebp-juan-francisco-maria-da-salud-donoso-cortes. 
